\title{
A Di-D-Fructose Dianhydride-Enriched Caramel Modulates Pig Fecal Microbiota Composition
}

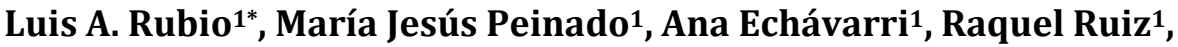 \\ Elena Suárez-Pereira ${ }^{2}$, Carmen Ortiz Mellet ${ }^{2}$, José M. García Fernández ${ }^{3}$ \\ ${ }^{1}$ Fisiología y Bioquímica de la Nutrición Animal (EEZ, CSIC), Granada, Spain \\ ${ }^{2}$ Departamento de Química Orgánica, Facultad de Química, Universidad de Sevilla, \\ Sevilla, Spain \\ ${ }^{3}$ Instituto de Investigaciones Químicas (IIQ), CSIC_-Universidad de Sevilla, Sevilla, Spain \\ Email: *Irubio@eez.csic.es
}

Received 26 November 2013; revised 5 January 2014; accepted 5 February 2014

Copyright (C) 2014 by authors and Scientific Research Publishing Inc.

This work is licensed under the Creative Commons Attribution International License (CC BY).

http://creativecommons.org/licenses/by/4.0/

(c) (i) Open Access

\section{Abstract}

A correlation has been previously described between bifidobacteria counts before and after the use of a dietary additive in human studies. However, to our knowledge no information on this topic has yet been reported in animals, and no information exists either on similar possible correlations of bacterial groups other than bifidobacteria. The potential prebiotic effects of di-D-fructose dianhydride (DFA)-enriched caramels have been previously reported in laboratory animals, poultry and pigs. In the present work, twelve growing male castrated pigs $(41.8 \pm 1.9 \mathrm{~kg}$ mean BW $)$ were fed in succession on a control (no additive) or DFA-enriched caramel $(20 \mathrm{~g} / \mathrm{kg})$ containing diet. Another group of 10 pigs $(38.0 \pm 3.7 \mathrm{~kg}$ mean $\mathrm{BW})$ fed on a control diet without any additive was used as negative control. Bacterial $\log _{10}$ number of copies of the $16 \mathrm{~S}$ rRNA gene was determined in fecal samples by using qPCR. Increased $(P<0.05)$ lactobacilli, Clostridium coccoides/Eubacterium rectale and bacteroides group $\log _{10}$ number of copies were determined in fecal samples of pigs fed on the caramel containing diet compared with non-caramel controls. In addition, for all bacterial groups studied microbiological values co-variated with initial counts and, except for enterobacteria, variations in the fecal bacterial numbers after caramel supplementation correlated $(P<0.05)$ with the fecal numbers before supplementation. In conclusion, the supplementation of pig diets with DFA-enriched caramels induced significant increases in the fecal number of copies of bacterial groups regarded as beneficial, and variations in the fecal number of copies correlated with the initial fecal number of copies.

*Corresponding author. 


\section{Keywords}

\section{Di-D-Fructose Dianhydrides, Fecal Microbiota, Correlations, Pig, Prebiotics}

\section{Introduction}

Evidence showing that antibiotic resistance genes can be transmitted from animal to human microbiota [1], and the detection of pathogenic bacteria resistant to a number of antimicrobial agents [2], have resulted in the full ban of antibiotic growth promoters (AGP) in animal production in the European Union from January 2006 onwards (EC Regulation 1831/2003; http://eur-lex.europa.eu/en/index.htm). This situation has imposed a high pressure on producers, leading also to an increased investigation on alternative new feed additives with the benefits of AGP, but without their observed drawbacks. Among these feed additives, some of the most studied are pre- and probiotics. Di-D-fructose dianhydride (DFA)-enriched caramels represent a promising group of additives with potential prebiotic effect which deserve experimental attention [3]. Their prebiotic effect has been previously reported in laboratory animals [4], poultry [5] and pigs [6].

A prebiotic is currently defined as "a selectively fermented ingredient that allows specific changes, both in the composition and/or activity in the gastrointestinal microbiota that confers benefits upon host wellbeing and health" [7]. Among the most widely studied and commercially used prebiotics are inulin, fructooligosaccharides (FOS), and galactooligosaccharides (GOS). Although partially fermented, prebiotics are recalcitrant to digestion by host-secreted enzymes in the small intestine, such that significant amounts reach the colon intact. They then become available to those members of the colonic microbiota considered as beneficial and metabolically equipped to metabolize these specific oligosaccharides.

On the other hand, some controversy exists in the literature on the influence, if any, of the dose utilized and of the starting number of bacteria on the effect of a given prebiotic [8]. This is potentially quite relevant because the effectiveness of a prebiotic on a given individual might depend, among other factors, also on the composition of the intestinal microbiota at the moment when it is introduced in the diet. Also, the effectiveness of including a given type of additive with prebiotic effect in the diet of a given individual might be anticipated to some extent. Accordingly, the aim of the present work was to determine if the effect of an additive, namely a DFA-enriched caramel obtained from D-fructose, on the counts of some groups of the pig's fecal microbiota might be correlated with the starting or initial values for those particular groups. This correlation has been previously described for bifidobacteria in human studies [7], but no information on this topic has yet been reported to our knowledge in animals. Also, no information exists on similar possible correlations of bacterial groups other than bifidobacteria. Finally, besides the potential interest of these additives in animal nutrition, the pig was also chosen as experimental animal in the current study because it is at present considered one of the best models for humans as far as intestinal physiology is concerned [9]. It is worth mentioning also that DFA are natural constituents of caramel [10] [11] and other sugar-rich foods, therefore being already present in the daily human diet.

\section{Materials and Methods}

\subsection{Additive, Animals and Sample Collection}

The caramel here used was obtained from D-fructose as previously described [12] [13], by using a newly developed technology to produce caramels with high DFA and glycosyl-DFA content ( $>60 \%)$. The procedure is based in the activation of D-fructose or mixtures of different carbohydrates containing D-fructose by strongly acidic ion-exchange resins. The final DFA-enriched caramel contained 18.5\% D-fructose, 31.6\% DAF and 48\% glycosyl-DAF.

Male castrated pigs of the Iberian breed were purchased from Sanchez Romero Carvajal S.A. (Huelva, Spain). Twelve animals (41.8 $\pm 1.9 \mathrm{~kg}$ mean $\mathrm{BW}$ ) were housed individually in $4 \mathrm{~m}^{2}$ pens in a temperature controlled $\left(20^{\circ} \mathrm{C} \pm 1^{\circ} \mathrm{C}\right)$ room. A commercial feed (Table 1) free of antibiotics or any other antimicrobial agents was used as control diet and given at about twice the maintenance requirement for energy ( $\mathrm{MEm}=458 \mathrm{~kJ}$ per $\mathrm{kg} 0.75$ BW). Pigs were fed in one meal of $1.5 \mathrm{~kg}$ per day at 09:00 a.m., and water was freely available from low pressure 
Table 1. Composition of the control diet.

\begin{tabular}{|c|c|}
\hline Component & $\mathrm{g} / \mathrm{kg}$ \\
\hline Wheat & 385 \\
\hline Barley & 300 \\
\hline Maize & 200 \\
\hline Maize gluten & 39 \\
\hline Soy concentrate $46 \%$ & 17 \\
\hline Soybean oil & 15 \\
\hline Calcium phosphate & 9 \\
\hline Calcium carbonate & 9 \\
\hline Sodium chloride & 5 \\
\hline Vit $+\min \operatorname{mix}^{1}$ & 10 \\
\hline Lysine & 6.2 \\
\hline Threonine & 1.5 \\
\hline Methionine & 0.3 \\
\hline Chromium oxide & 3 \\
\hline \multicolumn{2}{|l|}{ Calculated composition } \\
\hline Metabolizable energy $(\mathrm{kJ} / \mathrm{g})$ & 13.0 \\
\hline Crude protein & 130.0 \\
\hline Crude fiber & 35.6 \\
\hline Fat & 33.8 \\
\hline Calcium & 6.0 \\
\hline Phosphorous & 5.0 \\
\hline Methionine + Cysteine & 5.3 \\
\hline Lysine & 9.1 \\
\hline
\end{tabular}

${ }^{1}$ The vit. + min. mix contained (per kg): vitamin A, 500,000 IU; vitamin $\mathrm{D}_{3}$, 100,000 IU; vitamin E, $200 \mathrm{mg}$; vitamin $\mathrm{B}_{1}, 67 \mathrm{mg}$; vitamin $\mathrm{B}_{2}, 267 \mathrm{mg}$; vitamin $\mathrm{B}_{12}, 133 \mu \mathrm{g}$; vitamin $\mathrm{B}_{6}, 67 \mathrm{mg}$; calcium pantothenate, $667 \mathrm{mg}$; nicotinic acid, $1333 \mathrm{mg}$; folic acid, $25 \mathrm{mg}$; vitamin $\mathrm{K}_{3}, 67 \mathrm{mg}$; coline cloride, 6700 mg; Fe, 8000 mg; Cu, 1500 mg; Co, 0.75 mg; Zn, 7000 mg; Mn, 4000 mg; I, 42 mg; Se, 16 mg; etoxiquin, 66 mg.

drinking nipples. The animals were fed first on the control diet for $14 \mathrm{~d}$ and then on the caramel diet for another $14 \mathrm{~d}$ (11 d adaptation and $3 \mathrm{~d}$ collection periods in both cases). The caramel diet was the control diet supplemented with caramel (20 g/kg as fed basis). The caramel was solubilized in water (1:1 v:v) before it was mixed with the diet. Fecal samples were taken on days 12 - 14 in plastic bags immediately after they were produced after the morning feeding, and stored at $-80^{\circ} \mathrm{C}$. Samples from each day and animal were mixed, freeze dried and ground for further analysis [14]. Another group of 10 pigs (38.0 $\pm 3.7 \mathrm{~kg}$ mean $\mathrm{BW})$ fed only on a control diet for the same period of time was used as negative control. Fecal samples at the beginning (initial) and end (final) of the period were taken from this group of pigs as for the other group of animals. Comparisons between initial and final values were done for each group of animals. Values between groups were not compared. All management and experimental procedures carried out in this study were done in strict accordance with the appropriate practices for management of experimental animals in Spain (RD 1201/2005).

\subsection{Quantitative Real Time PCR Analysis}

Total DNA was isolated from freeze-dried fecal samples (40 mg) by using the QIAamp DNA stool kit (Qiagen, 
West Sussex, UK), and following manufacturer's instructions. In order to increase its effectiveness, the lysis temperature was increased to $95^{\circ} \mathrm{C}$ and an additional step with lysozyme $\left(10 \mathrm{mg} / \mathrm{mL}, 37^{\circ} \mathrm{C}, 30 \mathrm{~min}\right)$ incubation was added. Eluted DNA was treated with RNase and the DNA concentration assessed spectrophotometrically by using a NanoDrop ND-100 Spectrophotometer (NanoDrop Technologies, Wilmington, USA). Purified DNA samples were stored at $-20^{\circ} \mathrm{C}$ until use [14].

Bacterial log number of copies was determined in fecal samples by using qPCR. The 16S rRNA gene-targeted primers and PCR conditions used in this study are shown in Table 2. The qPCR assays were performed in polypropylene 96-well plates using an iQ5 Cycler Multicolor PCR detection system (BioRad laboratories, Hercules, CA, USA). The reaction mixture $(25 \mu \mathrm{L})$ comprised of $12.5 \mu \mathrm{L}$ of iQ SYBR Green Supermix (BioRad), $0.75 \mu \mathrm{L}$ of each of the specific primers ( $10 \mu \mathrm{M}$; Roche Diagnostics, Barcelona, Spain), $9 \mu \mathrm{L}$ of sterile distilled water and $2 \mu \mathrm{L}$ of DNA template. The fluorescent products were detected in the last step of each cycle. A melting curve analysis was carried out after amplification to distinguish the targeted PCR product from non-targeted PCR product. The melting curves were obtained by slow heating at temperatures from $55^{\circ} \mathrm{C}$ to $95^{\circ} \mathrm{C}$ at a rate of $0.5^{\circ} \mathrm{C}$ per $10 \mathrm{~s}$, with continuous fluorescence collection.

A plasmid standard containing the target region was generated using DNA extracted from pooled fecal samples. The amplified product was run on a $2 \%$ agarose gel, purified by MBL-Agarose QuickClean kit (Dominion MBL, Spain), cloned using the TOPOTA cloning kit (Invitrogen, Paisley, UK), and transformed into Escherichia coli One Shot Top 10 cells (Invitrogen). Plasmids were eluted by GenElute ${ }^{\mathrm{TM}}$ Plasmid Miniprep Kit (Sigma), sequences were obtained by the sequencing service of the Instituto de Parasitología y Biomedicina LópezNeyra (CSIC, Granada, Spain), and then submitted to the ribosomal RNA database (http://bioinformatics.psb.ugent.be/webtools/rRNA/blastrrna.htmL) in order to confirm the suitability of the primers. The concentration of the resulted products was determined by spectrophotometer and the copy number was calculated in terms of the product size. For quantification of target DNA copy number, a standard curve was generated using serial 10 -fold dilutions of the extracted product by using at least six nonzero standard concentrations per assay. The bacterial concentration in each sample was measured as $\log _{10}$ copy number by the interpolation of the $C_{t}$ values obtained by the fecal samples into the standard calibration curves. Each plate included duplicate reactions per DNA sample and the appropriate set of standards.

Table 2. Sequences of the primers used and q-PCR conditions for SYBR green 16 rDNA determination of microbial groups in pig fecal samples.

\begin{tabular}{|c|c|c|c|}
\hline Bacterial group & Primer & Reference & q-PCR conditions \\
\hline Total bacteria & $\begin{array}{l}\text { F-Eub } 338 \text { (ACTCCTACGGGAGGCAGCAG) } \\
\text { R-Eub } 518 \text { (ATTACCGCGGCTGCTGG) }\end{array}$ & [26] & $\begin{array}{l}\text { Initial denaturation: } 1 \text { cycle at } 50^{\circ} \mathrm{C} \text { for } \\
2 \text { min and } 95^{\circ} \mathrm{C} \text { for } 10 \mathrm{~min} \text {. Primer annealing } \\
\text { and product elongation: } 40 \text { cycles at } 95^{\circ} \mathrm{C} \\
\text { for } 15 \mathrm{~s} \text { and } 60^{\circ} \mathrm{C} \text { for } 1 \mathrm{~min} \text {. }\end{array}$ \\
\hline Lactobacilli & $\begin{array}{l}\text { F-lacto (GAGGCAGCAGTAGGGAATCTTC) } \\
\text { R-lacto (GGCCAGTTACTACCTCTATCCTTCTTC) }\end{array}$ & [27] & Idem \\
\hline Enterobacteria & $\begin{array}{l}\text { F5 (ATGGCTGTCGTCAGCTCGT) } \\
\text { R5 (CCTACTTCTTTTGCAACCCACTC) }\end{array}$ & [28] & Idem \\
\hline Bacteroides & $\begin{array}{l}\text { AllBac296F (GAGAGGAAGGTCCCCCAC) } \\
\text { AllBac412R (CGCTACTTGGCTGGTTCAG) }\end{array}$ & [29] & Idem \\
\hline $\begin{array}{l}\text { C. coccoides/ } \\
\text { E. rectale group }\end{array}$ & $\begin{array}{l}\text { g-Ссос-F (AAATGACGGTACCTGACTAA) } \\
\text { g-Cсос-R (CTTTGAGTTTCATTCTTGCGAA) }\end{array}$ & [30] & $\begin{array}{l}\text { Initial denaturation: } 94^{\circ} \mathrm{C} \text { for } 5 \text { min. } \\
\text { Primer annealing and product elongation: } \\
40 \text { cycles at } 94^{\circ} \mathrm{C} \text { for } 20 \mathrm{~s}, 50^{\circ} \mathrm{C} \text { for } 20 \mathrm{~s} \text {, } \\
\text { and } 72^{\circ} \mathrm{C} \text { for } 1 \mathrm{~min} \text {. }\end{array}$ \\
\hline C. leptum & $\begin{array}{l}\text { sg-Clept-F (GCACAAGCAGTGGAGT) } \\
\text { sg-Clept-R3 (CTTCCTCCGTTTTGTCAA) }\end{array}$ & [30] & Idem \\
\hline $\begin{array}{l}\text { Escherichia/ } \\
\text { Shigella group }\end{array}$ & $\begin{array}{l}\text { F5 (GTTAATACCTTTGCTCATTGA) } \\
\text { R5 (ACCAGGGTATCTAATCCTGTT) }\end{array}$ & [31] & $\begin{array}{l}\text { Initial denaturation: } 95^{\circ} \mathrm{C} \text { for } 10 \text { min. } \\
\text { Primer annealing and product elongation: } \\
35 \text { cycles at } 95^{\circ} \mathrm{C} \text { for } 15 \mathrm{~s}, 60^{\circ} \mathrm{C} \text { for } 20 \mathrm{~s} \text {, } \\
\text { and } 72^{\circ} \mathrm{C} \text { for } 30 \mathrm{~s} \text {. }\end{array}$ \\
\hline
\end{tabular}




\subsection{Statistical Analysis and Calculations}

Individual pigs were considered the experimental unit. Bacterial $\log _{10}$ number of copies was analyzed by 1-way ANOVA for each day and pig, and no differences were found for the three sampling days. Therefore, values for the three days were pooled and each initial or final value represents the mean of the values obtained for each of the three sampling days for each pig. The effect of DFA (Figure 1) was analyzed by 1-way repeated measures ANOVA using the MIXED procedure (SAS Inst. Inc., Cary, NC), and using $\log _{10}$ number of copies at day 0 of each period as covariate. Regression equations (Figure 2) were calculated where ordinate values (y) represent the $\log _{10}$ increase in number of copies in feces after caramel feeding respect to initial (control) $\log _{10}$ values, and abscissa (x) values were initial (control) $\log _{10}$ values. The $\log _{10}$ increase in number of copies was calculated as the $\log _{10}$ of the ratio of the number of copies after and before inclusion of DFA-enriched caramel in the diet. Regression equations and significances were obtained by using the REG procedure (SAS Inst. Inc., Cary, NC).

\section{Results}

The $\log _{10}$ number of copies of bacterial groups in feces of pigs fed on the control diet is shown in Table 3 . The final $\log _{10}$ numbers of lactobacilli, C. coccoides/E. rectale group, Clostridium leptum, enterobacteria and the Escherichia/Shigella group were lower $(P<0.05)$ than initial $\log _{10}$ number of copies. Final $\log _{10}$ numbers were not different for bacteroides and total bacteria.

As shown in Figure 1, increased $(P<0.05)$ lactobacilli, $C$. coccoides/E. rectale group and bacteroides, and decreased $(P<0.05)$ total bacterial $\log _{10}$ number of copies were found in fecal samples of pigs fed the diet containing DFA-enriched caramel as compared to the log number of copies determined in fecal samples of the same animals fed the control diet without additive. $\log _{10}$ number of copies of $C$. leptum, enterobacteria, and Escherichia/Shigella group in fecal samples of pigs fed diet containing DFA were not different from controls. In addition, for all bacterial groups studied microbiological values co-variated with initial counts. As shown in Figure 2,

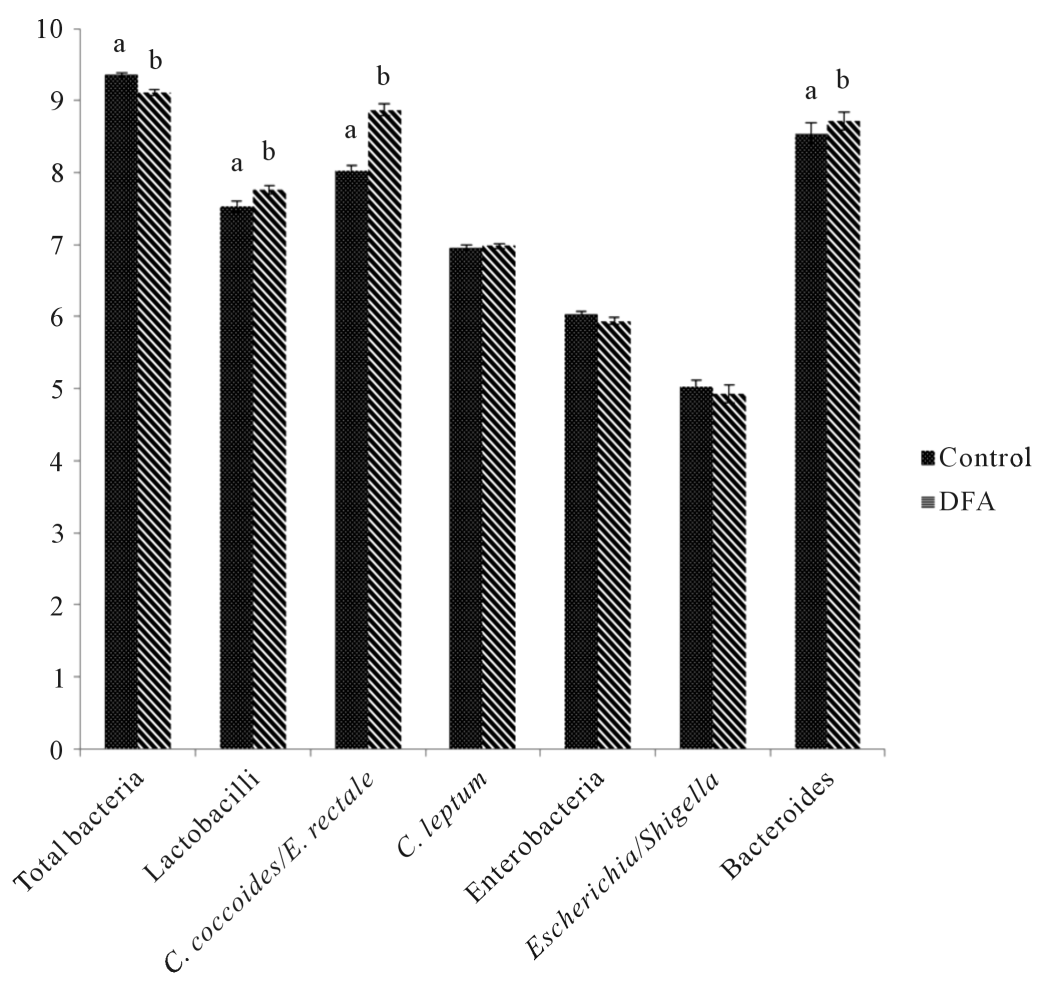

Figure 1. $\log _{10}$ number of copies/mg dry feces in pigs fed control (no additive) (dotted bars) or DFA-enriched caramel (striped bars) containing diets. Values are means of 36 values (12 pigs $\times 3$ days collection) with their SEM in bars. Bars with different letters for each bacterial group differ $(P<0.05)$. For all bacterial groups studied microbiological values co-variated with initial counts. 

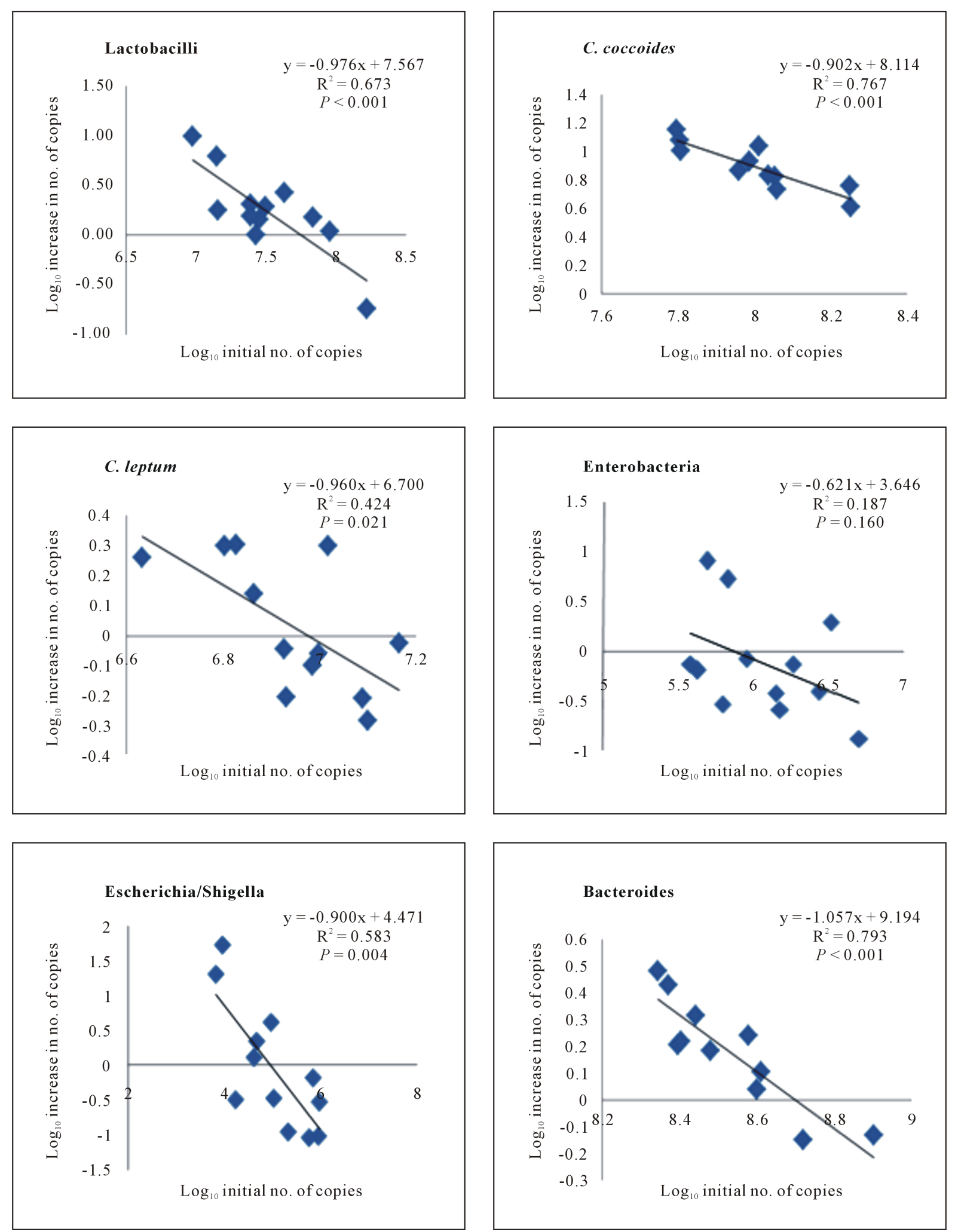

Figure 2. Correlation for each bacterial group studied of $\log _{10}$ fecal initial number of copies with the $\log _{10}$ increase in the fecal number of copies. The $\log _{10}$ increase in fecal number of copies was calculated as the $\log _{10}$ of the ratio of the number of copies after and before inclusion of DFA-enriched caramel in the diet. Each point represents the mean of three initial values against three increases for each of the 12 animals used in the experiment. 
Table 3. Initial and final bacterial $\log _{10}$ number of copies/mg of freeze-dried feces of Iberian pigs fed on a control diet.

\begin{tabular}{ccccc}
\hline & Initial & Final & Pooled SD & Significance level \\
\hline Total bacteria & 7.77 & 7.58 & 0.24 & 0.096 \\
Lactobacilli & $6.52^{\mathrm{a}}$ & $6.11^{\mathrm{b}}$ & 0.24 & 0.001 \\
C. coccoides/E. rectale & $6.01^{\mathrm{a}}$ & $5.75^{\mathrm{b}}$ & 0.25 & 0.028 \\
C. leptum & $5.17^{\mathrm{a}}$ & $4.72^{\mathrm{b}}$ & 0.21 & $<0.001$ \\
Enterobacteria & $4.45^{\mathrm{a}}$ & $3.11^{\mathrm{b}}$ & 0.68 & 0.001 \\
Escherichia/Shigella & $3.82^{\mathrm{a}}$ & $2.47^{\mathrm{b}}$ & 0.70 & $<0.001$ \\
Bacteroides & 6.61 & 6.48 & 0.33 & 0.386 \\
\hline
\end{tabular}

${ }_{\mathrm{a}, \mathrm{b}, \mathrm{c}}$ Means $(\mathrm{n}=10)$ in the same row with different superscript letters differ $(P<0.05)$.

the $\log _{10}$ increase in the fecal number of copies of lactobacilli, C. coccoides/E. rectale group, Escherichia/Shigella group and bacteroides after caramel feeding significantly $(P<0.01)$ correlated with the initial $\log _{10}$ fecal number of copies. The $\log _{10}$ final fecal number of copies of $C$. leptum after caramel feeding showed significant $(P<0.05)$ but lower correlations with the $\log _{10}$ increase in fecal number of copies. Correlation between enterobacteria $\log _{10}$ increase in no. of copies and $\log _{10}$ initial no. of copies was not significant. The regression equations, $\mathrm{R}^{2}$ values, and significance of regression curves are shown in Figure 2.

\section{Discussion}

The main task of the present work was to determine if the effect of an additive on the counts of some groups of the pig's fecal microbiota might be correlated with the starting or initial values for those particular groups. This is relevant because, if that was the case, the prebiotic effect of a putative prebiotic on a given individual would depend not only on factors linked to the prebiotic itself, but also on the composition of the intestinal microbiota at the moment when the prebiotic is introduced in the diet. In consequence, in some instances a low or null effect might be found not because the prebiotic was ineffective, but because of the composition of the microbiota in the particular model chosen. Also, more or less significant effects would be obtained in connection more with the microbial numbers at the beginning of the experiment than with prebiotic effectiveness as such.

The inclusion of DFA-enriched caramels in diets for pigs resulted in increased $\log _{10}$ number of copies of potentially beneficial bacteria (lactobacilli, C. coccoides/E. rectale group) in the feces (Figure 1), while values for those same groups decreased in pigs fed on the control diet (Table 3). This effect is similar to those found with a number of substances with potential (isomalto-oligosaccharides, lactosucrose, xylo-oligosaccharides) or confirmed (inulin, transgalacto-oligosaccharides, lactulose) prebiotic effect in humans [15]. Lactobacilli and bifidobacteria are generally regarded as beneficial bacteria for both humans and pigs [16], although bifidobacteria are believed to play only a minor role in the pig intestine [17]. As for the C. coccoides/E. rectale group, it includes bacteria producing butyric acid, a metabolite seen as beneficial for gut functionality and potentially protective against bowel cancer in humans [18]. In a previous report, Arribas et al. [4] showed that the administration of a DFA-enriched caramel obtained from fructose (containing $70 \%$ of an isomeric mixture of 13 DFAs and glycosyl-DFAs, identical to that used in this work) to colitic rats had an intestinal antiinflammatory effect, which was similar to that obtained with fructooligosaccharides (FOS) in the same experimental settings. The DFA-enriched caramel also promoted a more favorable intestinal microbiota, increasing lactobacilli and bifidobacteria counts as well as inducing increased concentrations of SCFA in the luminal colonic contents. These results are in line with those here found, and reinforce the concept of DFAs and glycosyl-DFAs as dietary beneficial compounds with potential prebiotic properties.

For all bacterial groups studied microbiological values co-variated with initial counts. In addition, as shown in Figure 2, the $\log _{10}$ increase in fecal number of copies of all the bacterial groups studied here except enterobacteria significantly correlated with the $\log _{10}$ initial fecal number of copies. It is clear that when studying the effect of a given prebiotic, it is important that a reliable and quantitative microbiological analysis of a wide variety of bacterial genera is carried out [19]. This is because the interactions among bacterial groups within the gastrointestinal tract are probably more important than variations in one single group. However, to our knowledge, this 
type of correlations has only been reported for bifidobacteria values and in human studies. Thus, Roberfroid et al. [20] reported that initial numbers of the bacteria that will be selectively stimulated to grow [the number before prebiotic administration] strongly determine the extent of stimulation [i.e. low if the initial number is high, but high if the initial number is low]. This was earlier reported by Hidaka et al. [21], and then confirmed in later studies both in vitro and in vivo [20] [22].

Correlations were stronger for lactobacilli, C. coccoides/E. rectale group, Escherichia/Shigella group and bacteroides. Among these, significant differences between absolute final and initial values were only determined for lactobacilli and C. coccoides/E. rectale group (Figure 1), probably because of the high standard deviations in the mean values of fecal bacterial number of copies among individual pigs. Pigs here used were from different litters, which probably resulted in higher variability in the initial fecal bacterial values. It is clear that a relationship between initial and final values can be demonstrated only if the same group of individuals having similar but somewhat different initial numbers of the studied bacteria is used. DGGE studies of pigs' intestinal microbiota have shown that each individual exhibits a unique bacterial community as demonstrated by stable and repeatable banding patterns [23]. This might give place to differences in prebiotic response. Janczyk et al. [24] have recently shown that the initial differences in the microbiota between pigs from different farms were responsible for differences in the small intestinal richness and diversity of the pigs fed diets containing prebiotics. In our case, differences in the initial values among individuals facilitate the study of the relationships between initial and final values because high and low relative initial values are required to study if the number before prebiotic administration determines the extent of stimulation. In the present study, the extent of stimulation in fecal bacterial number of copies was inversely correlated with initial values [lactobacilli, C. coccoides/E. rectale group and bacteroides]. For these bacterial groups, the higher the initial values, the lower the increase in the number of copies. In the groups for which fecal values tended to decrease respect to initial values [enterobacteria, C. leptum, Escherichia/Shigella group], the correlations were not so strong or not significant, except for Escherichia/Shigella group, probably because the effect on them is indirect, that is, consequent to the stimulation of growth of beneficial groups. It is generally accepted that beneficial bacteria may inhibit the colonization with pathogenic bacteria by competitive exclusion, by the stimulation of the immune response and by the production of antibacterial metabolites, such as lactic acid, VFA and bacteriocins [25]. The stimulation of the growth of some bacterial groups is most likely due to the fact that, as with other prebiotic substances, these are able to metabolize DAFs, while other groups are not. Studies with pure cultures are in course to test this hypothesis.

In conclusion, the inclusion of di-D-fructose dianhydride (DFA)-enriched caramels in diets for pigs induced significant increases in the fecal number of copies of lactobacilli and C. coccoides/E. rectale group, and variations in the fecal number of copies of all groups studied except enterobacteria correlated with fecal initial number of copies. Therefore, the effectiveness of a prebiotic on a given individual would depend, among other factors, also on the composition of the intestinal microbiota at the moment when it is introduced in the diet. This may be useful to anticipate the effectiveness of including a given type of additive with prebiotic effect in the diet of a given individual, and therefore facilitate a more specific use of this particular additive.

\section{Acknowledgements}

The authors are indebted to Dr. L. Lara for excellent technical assistance, to the Spanish MICIIN (SAF200802616 and SAF 2010-15670), and to the Spanish Junta de Andalucía (project AGR395) for financial support. This research has been also partially supported by the FEDER and FSE funds from the European Union. ES-P is a "Project of Excellence” Fellow (Junta de Andalucía, contract no. P06-AGR-02150).

\section{References}

[1] Greko, C. (2001) Safety Aspects on Non-Use of Antimicrobials as Growth Promoters. In: Piva, A., Bach Knudsen, K.E. and Lindberg, J.E., Eds., Gut Environment of Pigs, Nottingham University Press, Nottingham, 219-230.

[2] Aarestrup, F.M. (2003) Effects of Termination of AGP Use on Antimicrobial Resistance in Food Animals. Working Papers for the WHO International Review Panels Evaluation, Document WHO/CDS/CPE/ZFK/2003.1a, World Health Organization, Geneva, 6-11.

[3] Ortiz Mellet, C. and García Fernández, J.M. (2010) Difructose Dianhydrides (DFAs) and DFA Enriched Products as Functional Foods. Topics in Current Chemistry, 294, 49-77. http://dx.doi.org/10.1007/128_2010_50

[4] Arribas, B., Suárez-Pereira, E., Ortiz Mellet, C., García Fernández, J.M., Buttersack, C., Rodríguez-Cabezas, M.E., 
Garrido-Mesa, N., Bailon, E., Guerra-Hernández, E., Zarzuelo A. and Gálvez, J. (2010) Di-D-Fructose-Enriched Caramels: Effect on Colon Microbiota, Inflammation, and Tissue Damage in Trinitrobenzenesulfonic Acid-Induced Colitic Rats. Journal of Agricultural and Food Chemistry, 58, 6476-6484. http://dx.doi.org/10.1021/jf100513j

[5] Orban, J.I., Patterson, J.A., Sutton, A.L. and Richards, G.N. (1997) Effect of Sucrose Thermal Oligosaccharide Caramel, Dietary Vitamin-Mineral Level, and Brooding Temperature on Growth and Intestinal Bacterial Populations of Broiler Chickens. Poultry Science, 76, 482-490. http://dx.doi.org/10.1093/ps/76.3.482

[6] Orban, J.I., Patterson, J.A., Sutton, A.L. and Richards, G.N. (1996) Growth Performance and Intestinal Microbial Populations of Growing Pigs Fed Diets Containing Sucrose Thermal Oligosaccharide Caramel. Journal of Animal Science, 74, 170-175.

[7] Roberfroid, M.B. (2007) Prebiotics: The Concept Revisited. Journal of Nutrition, 137, 830S-837S.

[8] Davis, L.M.G., Martínez, I., Walter, J. and Hutkins, W. (2010) A Dose Dependent Impact of Prebiotic Galactooligosaccharides on the Intestinal Microbiota of Healthy Adults. International Journal of Food Microbiology, 144, $285-292$. http://dx.doi.org/10.1016/j.ijfoodmicro.2010.10.007

[9] Metges, C.C. (2010) Classical and Post-Genomic Methods to Study GIT Function with Emphasis on the Pig. Livestock Science, 133, 10-19. http://dx.doi.org/10.1016/j.livsci.2010.06.014

[10] Defaye, J. and García Fernández, J.M. (1994) Protonic and Thermal Activation of Sucrose and the Oligosaccharide Composition of Caramel. Carbohydrate Research, 256, C1-C4. http://dx.doi.org/10.1016/0008-6215(94)84219-1

[11] Defaye, J. and García Fernández, J.M. (1995) The Oligosaccharide Components of Caramel. Zuckerindustrie, 120, 700-704.

[12] Rubio, E.M., Gómez, M., Ortiz-Mellet, C., García-Fernández, J.M., Zarzuelo, A., Gálvez J.J. and Duval, R. (2007) Novel Caramels with a High Prebiotic Oligosaccharide Content. ES Patent WO2008107506.

[13] Suárez-Pereira, E., Rubio, E.M., Pilard, S., Ortiz-Mellet, C. and García-Fernández, J.M. (2010) Di-D-Fructose Dianhydrade (DFA)-Enriched Caramels by Acid Ion-Exchange Resin-Promoted Caramelization of D-Fructose: Chemical Analysis. Journal of Agricultural and Food Chemistry, 58, 1777-1787. http://dx.doi.org/10.1021/jf903354y

[14] Ruiz, R. and Rubio, L.A. (2009) Lyophyllization Improves the Extraction of PCR-Quality Community DNA from Pig Fecal Samples. Journal of the Science of Food and Agriculture, 89, 723-727. http://dx.doi.org/10.1002/jsfa.3465

[15] Candela, M., Maccaferri, S., Turoni, S., Carnevali, P. and Brigidi, P. (2010) Functional Intestinal Microbiome, New Frontiers in Prebiotic Design. International Journal of Food Microbiology, 140, 93-101. http://dx.doi.org/10.1016/j.ijfoodmicro.2010.04.017

[16] Gaggìa, F., Mattarelli, P. and Biavati, B. (2009) Probiotics and Prebiotics in Animal Feeding for Safe Food Production. International Journal of Food Microbiology, 141, S15-S28. http://dx.doi.org/10.1016/j.ijfoodmicro.2010.02.031

[17] Mikkelsen, L.L., Bendixen, C., Jakobsen, M. and Jensen, B.B. (2003) Enumeration of Bifidobacteria in Gastrointestinal Samples from Piglets. Applied and Environmental Microbiology, 69, 654-658. http://dx.doi.org/10.1128/AEM.69.1.654-658.2003

[18] Kleessen, B., Hartman, L. and Blaut, M. (2001) Oligofructose and Long Chain Inulin Influence the Gut Microbial Ecology of Rats Associated with a Human Fecal Flora. British Journal of Nutrition, 86, 291-300. http://dx.doi.org/10.1079/BJN2001403

[19] Gibson, G.R., Probert, H.M., Van Loo, J., Rastall, R.A. and Roberfroid, M.B. (2004) Dietary Modulation of the Human Colonic Microbiota: Updating the Concept of Prebiotics. Nutrition Research Reviews, 17, 259-275. http://dx.doi.org/10.1079/NRR200479

[20] Roberfroid, M.B., Van Loo, J.A.E. and Gibson, G.R. (1998) The Bifidogenic Nature of Chicory Inulin and Its Hydrolysis Products. Journal of Nutrition, 128, 11-19.

[21] Hidaka, H., Eida, T., Takizawa, T., Tokunaga, T. and Tashiro, Y. (1986) Effects of Fructo-Oligosaccharides on Intestinal Flora and Human Health. Bifidobacteria and Microflora, 5, 37-50.

[22] Rycroft, C.E., Jones, M.R., Gibson, G.R. and Rastall, R.A. (2001) Fermentation Properties of Gentio-Oligosaccharides. Letters in Applied Microbiology, 32, 156-161. http://dx.doi.org/10.1046/j.1472-765x.2001.00875.x

[23] Simpson, J.M., McCracken, V.J., Rex Gaskins, H. and Mackie, R.I. (2000) Denaturing Gradient Gel Electrophoresis Analysis of 16S Ribosomal DNA Amplicons to Monitor Changes in Fecal Bacterial Populations of Weaning Pigs after Introduction of Lactobacillus reuteri Strain MM53. Applied and Environmental Microbiology, 66, 4705-4714. http://dx.doi.org/10.1128/AEM.66.11.4705-4714.2000

[24] Janczyk, P., Pieper, R., Smidt, H. and Souffrant, B. (2010) Effect of Alginate and Inulin on Intestinal Microbial Ecology of Weanling Pigs Reared under Different Husbandry Conditions. FEMS Microbiology Ecology, 72, 132-142. http://dx.doi.org/10.1111/j.1574-6941.2009.00826.x

[25] Guarner, F., Khan, A.G., Garisch, J., Eliakim, R., Gangl, A., Thomson, A., Krabshuis, J. and Lemair, T. (2011) Probio- 
tics and Prebiotics. World Gastroenterology Organisation, Milwaukee.

[26] Guo, X., Xia, X., Tang, R., Zhou, J., Zhao, H. and Wang, K. (2008) Development of a Real-Time PCR Method for Firmicutes and Bacteroidetes in Feces and Its Application to Quantify Intestinal Population of Obese and Lean Pigs. Letters in Applied Microbiology, 47, 367-373. http://dx.doi.org/10.1111/j.1472-765X.2008.02408.x

[27] Delroisse, J.M., Bolvin, A.L., Parmentier, I., Dauphin, R.D., Vandenbol, M. and Portetelle, D. (2008) Quantification of Bifidobacterium spp. and Lactobacillus spp. in Rat Fecal Samples by Real-Time PCR. Microbiology Research, 163, 663-670. http://dx.doi.org/10.1016/j.micres.2006.09.004

[28] Castillo, M., Martin-Orue, S.M., Manzanilla, E.G., Badiola, I., Martin, M. and Gasa, J. (2006) Quantification of Total Bacteria, Enterobacteria and Lactobacilli Populations in Pig Digesta by Real-Time PCR. Veterinary Microbiology, 144, 165-170. http://dx.doi.org/10.1016/j.vetmic.2005.11.055

[29] Layton, A., McKay, L., Williams, D., Garrett, V., Gentry, R. and Sayler, G. (2006) Development of Bacteroides 16S rRNA Gene Taqman-Based Real-Time PCR Assays for Estimation of Total, Human and Bovine Fecal Pollution in Water. Applied and Environmental Microbiology, 72, 4214-4224. http://dx.doi.org/10.1128/AEM.01036-05

[30] Matsuki, T., Watanabe, K., Fujimoto, J., Takada, T. and Tanka, R. (2004) Use of 16S rRNA Gene-Targeted GroupSpecific Primers for Real-Time PCR Analysis of Predominant Bacteria in Human Feces. Applied and Environmental Microbiology, 70, 7220-7228. http://dx.doi.org/10.1128/AEM.70.12.7220-7228.2004

[31] Malinen, E., Kassinen, A., Rinttilä, T. and Palva, A. (2003) Comparison of Real-Time PCR with SYBR Green I or 5’Nuclease Assays and Dot-Blot Hybridization with rDNA-Targeted Oligonucleotide Probes in Quantification of Selected Fecal Bacteria. Microbiology, 149, 269-277. http://dx.doi.org/10.1099/mic.0.25975-0 